草

\title{
Collider Scenario Implications of ASST Operation
}

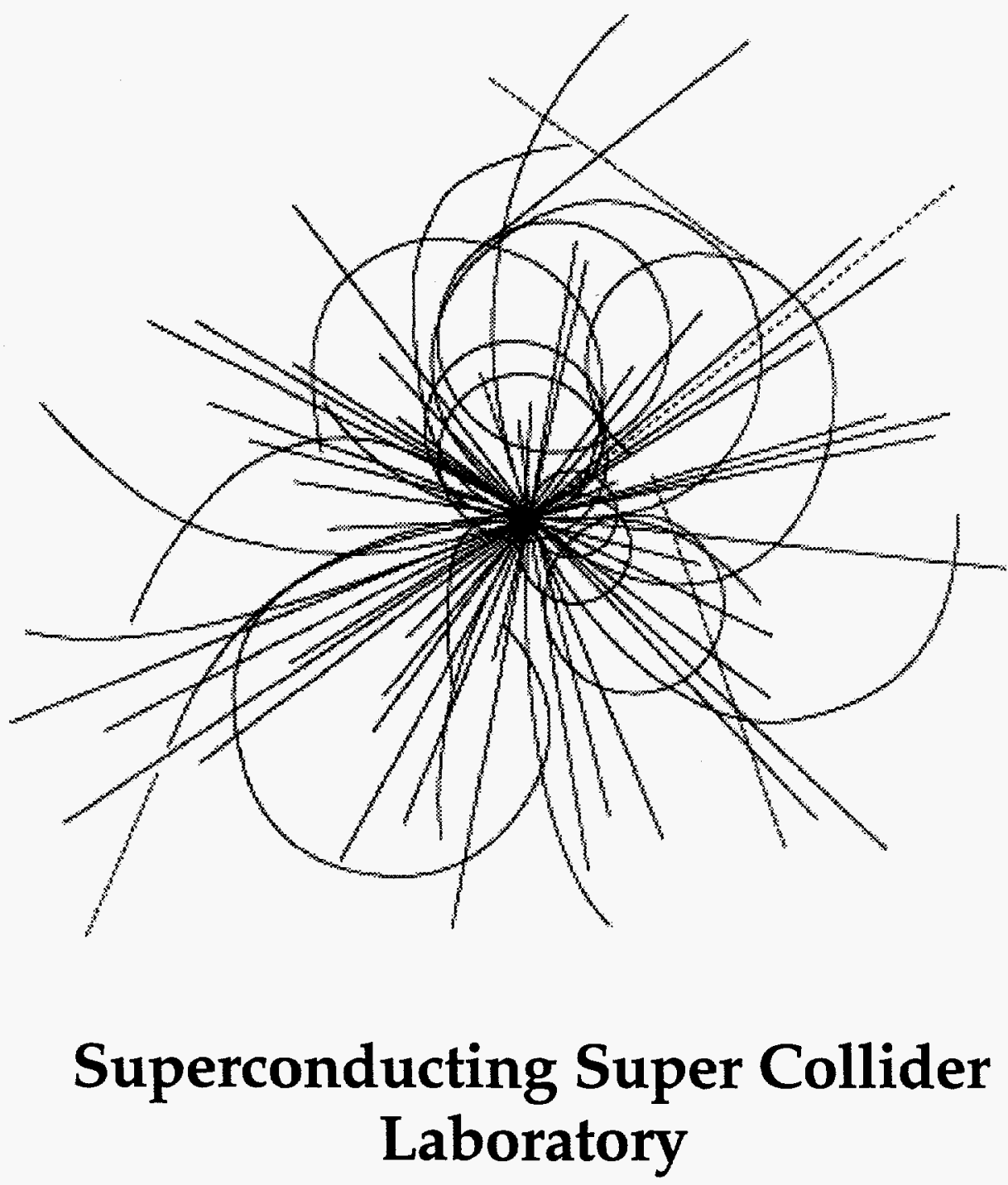

APPROVED FOR RELEASE OR

PUBLICATION - O.R. PATENT GROUP BY............ DATE. \$1.9.\%.
A. McInturff

W. Burgett

M. Christianson

T. Dombeck

J. Gannon

D. Haenni

P. Kraushaar

M. Levin

M. McAshan

G. Mulholland

D. Murray

W. Robinson

T. Savord

R. Smellie

F. Spinos

G. Tool

J. Weisend II

J. Zatopek 


\section{Disclaimer Notice}

This report was prepared as an account of work sponsored by an agency of the United States Government. Neither the United States Govemment or any agency thereof, nor any of their employees, makes any warranty, express or implied, or assumes any legal liability or responsibility for the accuracy, completeness, or usefulness of any information, apparatus, product, or process disclosed, or represents that its use woutd not infringe privately owned rights. Reference herein to any specific commercial product, process, or service by trade name, trademark, manufacturer, or otherwise, does not necessarily constitute or imply its endorsement, recommendation, or favoring by the United States Government or any agency thereof. The views and opinions of authors expressed herein do not necessarily state or reflect those of the United States Government or any agency thereof. 


\section{DISCLAIMER}

Portions of this document may be illegible in electronic image products. Images are produced from the best available original document. 
SSCL-Preprint-434

\title{
Collider Scenario Implications of ASST Operation*
}

\author{
A. McInturff, W. Burgett, M. Christianson, T. Dombeck, J. Gannon, D. Haenni, \\ P. Kraushaar, M. Levin, M. McAshan, G. Mulholland, D. Murray, W. Robinson, \\ T. Savord, R. Smellie, F. Spino, G. Tool, J. Weisend II, and J. Zatopek
}

\author{
Superconducting Super Collider Laboratory ${ }^{\dagger}$ \\ 2550 Beckleymeade Ave. \\ Dallas, TX 75237
}

May 1993

\section{DISCLAIMER}

\begin{abstract}
This report was prepared as an account of work sponsored by an agency of the United States Government. Neither the United States Government nor any agency thereof, nor any of their employees, makes any warranty, express or implied, or assumes any legal liability or responsibility for the accuracy, completeness, or usefulness of any information, apparatus, product, or process disclosed, or represents that its use would not infringe privately owned rights. Reference herein to any specific commercial product, process, or service by trade name, trademark, manufacturer, or otherwise does not necessarily constitute or imply its endorsement, recommendation, or favoring by the United States Government or any agency thereof. The views and opinions of authors expressed herein do not necessarily state or reflect those of the United States Government or any agency thereof.
\end{abstract}

\footnotetext{
*Presented at the 1993 IEEE Particle Accelerator Conference on May 17-20, Washington, D.C.

'Operated by the Universities Research Association, Inc., for the U.S. Department of Energy under Contract No. DE-AC35-89ER40486.
} 


\title{
Collider Scenario Implications of ASST Operation
}

\author{
A. D. McInturff, W. Burgett, M. Christianson, T. Dombeck, J. Gannon, D. Haenni, P. Kraushaar, M. Levin, M. McAshan, \\ G. Mulholland, D. Murray, W. Robinson, T. Savord, R. Smellie, F. Spinos, G. Tool, J. Weisend II, and J. Zatopek \\ Superconducting Super Collider Laboratory ${ }^{\dagger}$ \\ 2550 Beckleymeade Avenue, Dallas, TX 75237
}

\section{Abstract}

After the achievement of the SSCL's Congressionally mandated milestone, the Accelerator System String Test (ASST) half cell under went a series of power tests. These tests involved quenches induced in various configurations and in power levels up to the maximum operation point. These tests have produced data which has defined various parameters and requirements for the individual elements and system.

\section{INTRODUCTION}

After careful data analysis of the first operational period of the ASST, and its comparison to previous string data, $[1,2]$ there were a series of unanswered questions and unmeasured or unacceptable parameters that needed to be addressed. [3] There were also a few problems encountered during the preliminary run that experimentally limited the parameter range available. The half end spool's $20 \mathrm{~K}$ control valve and lines' problem required their rerouting and its replacement. See Fig. 1. These repairs and changes resulted in lower flow rates for the end spool power leads. The required $20 \mathrm{~K}$ shield flow rate during power cycles decreased by a factor of 5 to 10 . The low high voltage breakdown of all the spool's voltage tap connectors required their replacement. See Fig. 2. The ultimate cold hipot limit of the high voltage and current bus plus voltage taps increased from 700 volts to $2.6 \mathrm{KV}$ in $4.6 \mathrm{~K}$, 4 ATM helium. The ability to reconfigure the half cell for various special tests (i.e., the spool piece containing recooler "SPR's" safety leads' response) was implemented. There were also a series of special experiments that had been requested and subsequently approved to be done as schedule permitted in addition to the standard verification of the operation range. Induced quenches up to and including the peak operating field were performed. A series of thermal load measurements were taken as well. In addition to the 21 induced quenches that occurred during the initial summer run, the half cell was subjected to 18 more induced quenches including 8 at $6.5 \mathrm{KA}$.

\section{EXPERIMENTAL PROCEDURE}

The typical procedure followed first validates the quench protection system. Then the string is powered below the cryostable point and the system's energy is discharged into the dump resistor. Subsequently at a magnet current a few hundred amperes over the cryostable point, at least one heater circuit per magnet is powered to check its ability to drive the coils normal. The third dipole in the string, which is connected to

†Operated by Universities Research Association, Inc., for the U.S. Department of Energy under Contract No. DE-AC35-89ER40486. the lower buss, had in earlier string tests produced the highest quench voltages $[2,3]$. Therefore, it was decided to induce quenches in this dipole at $500 \mathrm{Amps}$ intervals up to 6.5 kilo amps until it was deemed prudent not to, because of high voltage. After completing a series of induced quenches at the maximum operating fields, the energy of the string was dissipated into an external dump in order to bracket the maximum down ramp rate that the half cell could be full field de-energized and stay superconducting. The value of the dump resistor was varied from 12 to $16 \mathrm{~m} \Omega$ to obtain the various ramp rates. The next experiment was a series of spot heater quenches induced from $5.0 \mathrm{KA}$ to $6.5 \mathrm{KA}$ in the third dipole to simulate a spontaneous quench. The string was reconfigured such that the current from the power supply (see figure 2) entered the "SPR" safety lead (upper buss) from a group of MCM cables, on the floor parallel to the first 5 dipoles. Once in the cryostat it passed through the quadrupole windings and exited the cryostat through the end spool power lead. After exiting the end spool power lead it returns to the power supply via another set of MCM cables on the floor. The reconfiguration scheme for the lower buss safety lead was for current to enter the lower buss power lead in the end spool and exit the lower buss safety lead in the "SPR." The last experiment was a spot heater induced quench in the first dipole.

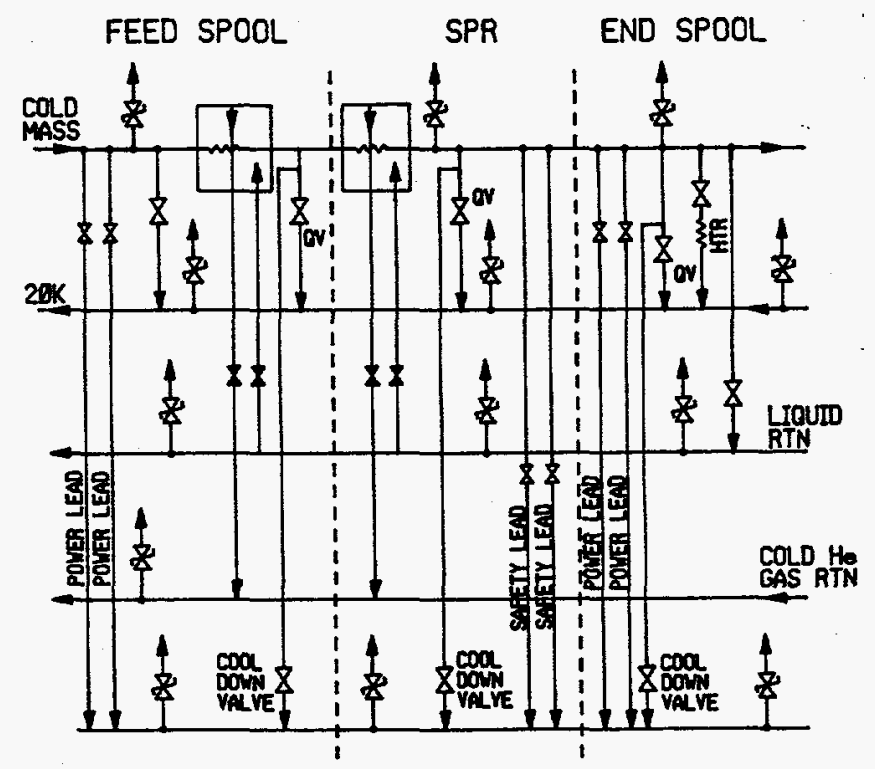

Figure 1. Cryogenic Diagram

The cryogenic loads were measured after the system had been at operational temperature, commissioned, and completed $75 \%$ of the experimental program. The system was held at the operating conditions with the notable exceptions of the full 
operational flow and $4.6 \mathrm{~K}$ instead of $4.25 \mathrm{~K}$ due to the size of the refrigerator available. There were also a series of load resistors placed in the various cryogenic circuits that loads were to be determined. This allowed an independent heat load measurement calibration and error determination.

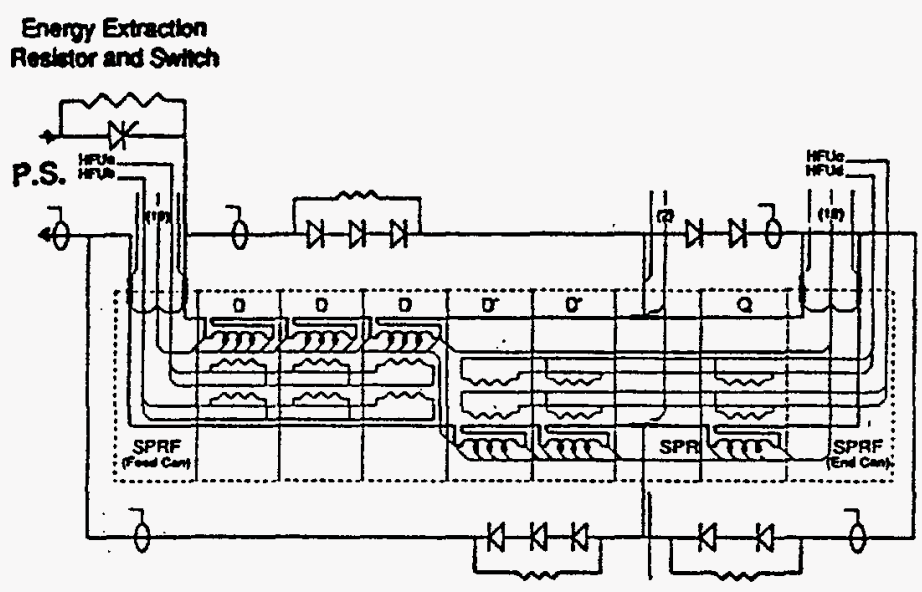

Figure 2. Electrical Diagram

The heat load measurement ${ }^{[4]}$ for the ASST appears to be influenced by end effects originating in the feed spool, recooler spool piece, and the special end spool. After the end spool repair, the heat load in the return end of the half cell appeared to be significantly reduced.

The sequencing of the quench valve versus position of the initial quenching element evolved during the commissioning. This was done in an attempt to confine the quenched volume to a quarter cell.

\section{RESULTS}

The commissioning test and validation checks of the QPS and associated hardware required twelve SCR switched events that resulted in de-energizing the half cell into the "dump resistor." These dumps varied from 500 to $6500 \mathrm{Amps}$. There were no problems encountered during these dump sequences. There was a mechanical "backup" switch to the SCR's. This being required due to the most common anticipated failure mode being an inability to gate the SCR's off. There were three "mechanically" switched opened events (SCR'S having been not activated for these tests) which were done at 500 Amps, 4000 Amps and 6500 Amps. The mechanical switch performed satisfactorily during these tests. There were also two 6500 Amps dumps made with different values for the dump resistor in order to bracket the maximum down rate that the half cell would operate and not quench in the process. The power lead voltages tripped the "QPS" on two occasions, but did not result in the half cell magnetic elements going normal. The first occurred because of the original $20 \mathrm{~K}$ valve and lines' problem which required a flow adjustment to correct. This additional flow and shield operation was later reversed on the second run by correction of the end spool problem. The second trip was due to the lead flow being turned up too late before the ramping cycle had started, therefore, leaving the lead cold flag temperature too high.
The additional two higher resistance dumps were performed to determine the maximum rate at which the half cell could be de-energized and stay superconducting. Those values used were 12 and 16 milliohms. These data points indicated that at an operating temperature of $4.6 \mathrm{~K}$ the half cell would not quench on the down ramp from 6500 amps at a rate of $258 \mathrm{~A} / \mathrm{sec}$, however, it would quench on a $328 \mathrm{~A} / \mathrm{sec}$ one. These results will be repeated and possibly bracketed closer during the next full cell run this summer and at the lower operating temperature of $4.3 \mathrm{~K}$. The magnet protection is divided up so that the QPS will quench either the upper or lower buss magnets and bypass them and continue to down ramp the other quarter cell. In the case of the $328 \mathrm{~A} / \mathrm{sec}$ down rate magnets from both busses went normal. The upper buss (last in the helium coolant path) magnets were slightly ahead of the lower buss magnets, 4.46 and 4.82 seconds into the down ramp, respectively. This resulted in the upper buss magnet (D4) receiving 10.3 Miits and the lower buss magnet (D1) 9.8 Mitts . "Miits" is defined as million ampere squared seconds of energy into the original "normal" volume per unit resistance. The quench occurred at a current of 5300 amps and produced only 230 volt to ground. This resulted in a helium pressure wave with a peak of 170 psig which was very typical of $6500 \mathrm{Amp}$ quenches. Therefore, it appears that the planned $200 \mathrm{~A} / \mathrm{sec}$ down ramp at $4.3 \mathrm{~K}$ is probably not a constraint, and could be slightly increased.

The commissioning tests comprised a series of twelve protection strip heater induced quenches at $2000 \mathrm{Amps}$ ( 300 to 500 Amps greater than the cryostable point of the conductor used in the coil windings). These tests were performed to insure that the protection strip heater could indeed drive their associated magnets normal at a low enough current that the magnets were not at risk. The remaining induced quenches were done to study the peak Miits, the maximum voltage to ground and the peak pressure generated in the helium.

There were several interesting aspects to these data; first the voltage to ground which will only be briefly mentioned as it is a subject of another paper this conference [5]. The maximum observed voltage to ground was $1700^{+}$volts during an induced quench at 6000 Amps. This result would have scaled to 2300 volts at $6500 \mathrm{Amps}$ and the system was subsequently hipotted to 2600 volts after this event. This, of course, assumes that the voltage would have continued to rise at its previous rate from earlier quenches at lower currents. The "Miits" appeared to be leveling off in the 9 to 11 region with a solder melt limit being approximately $16^{+}$Miits. The parameter that correlated to this particular magnet producing high voltage was its relatively high low temperature resistance compared to the other elements in the quarter cell that were bussed in series with it. This has lead to an additional requirement that the low temperature resistance of the units in the quarter cells have the same outer coil value within $10 \%$.

The high pressure helium wave front that is generated by the quench was carefully measured to ascertain magnitude and speeds. It appears that there is a large pressure drop across the recooler when the pressure front passes through it. The peak pressure observed during an induced quench event was 205 psig. This occurred when a quench was strip heater induced in the dipole next to the "SPR" at 6500 amps. The quench valve that had been activated to relieve the pressure was on the opposite side of the recooler. 
The spot heater quench events which simulate some types of spontaneous quenches could be compared to strip heater quenches as follows; a) the Miits at a given current were larger by approximately $10 \%$; b) the peak voltage to ground was about one half plus or minus $10 \%$. These characteristics were valid for both magnets, D1 and D3 for which data existed for comparison.

The "SPR" safety leads' resistance ranged between 0.9 to 1.3 milliohms according to the duration and history of their powering. The thermal time constant for their exit gas temperature appears to be $\sim 20$ minutes. The response of the quench stopper located at the base of the safety lead suggests the lead thermal time constant to be on the order of hours. The lead design has a very large safety factor. It was tested to twice the energy input required for a standard ramp down and it did not raise the superconducting cable side of the quench stopper more than a few 100 milliKelvins. Therefore, it would seem possible to reduce its present size and subsequent heat leak. The time to remove the heat from the present safety lead even with the lead gas flow greater than $120 \mathrm{l} / \mathrm{sec}$ is on the order of hours. This represents an operational constraint and must be mitigated. The quench stopper in the "SPR" was able to keep the buss stabilized even with $\Delta \mathrm{T}$ of $16 \mathrm{~K}$ across it.

The thermal measurements on the string are summarized in Table 1 [4].

Table 1. Cryogenic Load for Various Circuits Watts/(Dipole + Interconnect)

\begin{tabular}{|c|c|c|c|c|c|c|c|c|c|}
\hline $\begin{array}{l}\text { Circuit } \\
\text { /Run \# }\end{array}$ & $\begin{array}{c}\% \\
\text { Error }\end{array}$ & $\begin{array}{l}\text { Feed } \\
\text { Spool } \\
* *\end{array}$ & D1 & D2 & D3 & D4 & D5 & SPR & $\mathrm{Bgt}$ \\
\hline $\begin{array}{l}\text { Cold } \\
\text { Mass/1 }\end{array}$ & \pm 33 & $\begin{array}{l}\text { Large } \\
\text { Load? }\end{array}$ & 9.5 & 2.4 & 0.4 & 1.7 & 4.1 & $\begin{array}{l}(30- \\
40)^{*}\end{array}$ & .36 \\
\hline $\begin{array}{l}\text { Cold } \\
\text { Mass/2 }\end{array}$ & \pm 28 & $\begin{array}{l}\text { Large } \\
\text { Load? }\end{array}$ & 9.0 & 2.4 & --- & 1.5 & 2.2 & $\begin{array}{l}(20- \\
6)^{*}\end{array}$ & .36 \\
\hline $20 \mathrm{~K} / 2$ & \pm 01 & $\cdots$ & 9.6 & 4.8 & --- & 5.2 & 3.8 & --- & \\
\hline $\begin{array}{l}80 \mathrm{~K} / 1 \\
80 \mathrm{~K} / 2\end{array}$ & $\begin{array}{l} \pm 14 \\
\pm 16\end{array}$ & $\cdots$ & $\begin{array}{l}27 . \\
23 .\end{array}$ & $\begin{array}{l}29 . \\
25 .\end{array}$ & $\begin{array}{l}26 \\
23\end{array}$ & $\begin{array}{l}16 \\
13\end{array}$ & $\begin{array}{l}20 . \\
19 .\end{array}$ & --- & \\
\hline
\end{tabular}

The minimum total load estimate of the liquid return and cold mass was $\sim 130$ watts, therefore, this would indicate the end spools are $>40 \mathrm{w}$ each. As can be seen in the table, there are indications that the high heat leaks present in the end and feed spool pieces corrupt the cold mass thermal load measurement.

\section{CONCLUSIONS}

These data and those obtained from other experiments not presented have modified our approach to collider operations. Several problems will need to be addressed to limit their impact. The pump out times for the system have been modified. The maximum operating pressure is now determined by the cool down rate not quench pressure. The design of the safety lead will be revised with respect to quench recovery time. The high coldmass heat load will have to be understood.
This is particularly true because of the differences with the earlier lower $40 \mathrm{~mm}$ string coldmass load measurements. The low temperature $<20 \mathrm{~K}$ resistance of the outer windings of the magnets in a quarter cell will be matched to $10 \%$. There were however no data obtained that would preclude a successful collider operation.

\section{ACKNOWLEDGMENTS}

The authors would like to recognize the contribution of the many individuals and groups to the operation of the half cell during these tests. The cryogenics crew chief, R. Ahlman, the string assembly crew chief, C. White, and operations tech supervisor, M. Hentges, and all the members of their teams deserve a special vote of thanks for the long hours.

\section{REFERENCES}

[1] A. McInturff, R. Flora, B. Norris, J. Theilacker, D. Wolff, S. Augustynowicz, C. Dickey, G. Tool, D. Wallis, and J. G. Weisend II. IEEE Trans. on Mag. Vol. 28, No. 1, 512 (1992).

[2] A. McInturff, S. Augustynowicz, W. Burgett, R. Coombes, C. Dickey, T. Dombeck, W. Feitz, R. Flora, J. Gannon, D. Haenni, P. Kraushaar, M. Levin, M, McAshan, G. Mulholland, D. Murray, W. Robinson, T. Savord, F. Spinos, G. Tool, J. Weisend II, D. Wallis, D. Voy, and J. Zbasnik, IEEE Trans. on Applied Superconductivity. Vol. 3, No. 1, 622 (1993).

[3] W. Burgett, M. Christianson, T. Dombeck, J. Gannon, D. Haenni, P. Kraushaar, M. Levin, M, McAshan, A. McInturff, G. Mulholland, D. Murray, W. Robinson, T. Savord, R. Smellie, F. Spinos, G. Tool, J. Weisend II, and J. Zatopek. "Full-Power Test of a String of Magnets Comprising a Half Cell of the Superconducting Super Collider" to be published in Particle Accelerators.

[4] W. Burgett, D. Franks, P. Kraushaar, M. Levin, M. McAshan, A. McInturff, R. Pletzer, D. Revell, W. Robinson, V. Saladin, G. Shuy, R. Smellie, and J. Weisend, II. "Cryogenic Characteristics of the SSC Accelerator Systems String Test (ASST)" to be published in Proceedings of the Fifth IISSC, USA, 1993.

[5] W. Robinson, W. Burgett, T. Dombeck, J. Gannon, P. Kraushaar, A. McInturff, T. Savord, and G. Tool, "Electrical Performance Characteristics of the SSC Accelerator System String Test." Paper N3 this conference. 